\title{
Antinomy of Community Participation Rights in the Law on the Environmental Sector
}

\author{
Febriansyah Ramadhan ${ }^{*}$ and Ilham Dwi Rafiqi**) \\ *) Faculty of Law, Universitas Brawijaya, Indonesia Email: \\ mrfebri18@gmail.com \\ $\left.{ }^{* *}\right)$ Faculty of Law, Universitas Muhammadiyah Malang, Indonesia Email: \\ ilhamdwirafiqi@umm.ac.id
}

\begin{abstract}
Issues of deprivation of rights and discrimination are topics that are always discussed in Indonesia, which is known as a democracy. Community participation is one of the important instruments for indicators of the success of democracy in a country which is carried out in various sectors of life. This research will look at how to regulate community participation rights, especially in the development sector and environmental management. This study uses normative juridical research with a statutory and conceptual approach. The results of the study indicate that conceptually the right of community participation in the environmental sector is an elaboration of the guarantee of good and healthy environmental rights. The right to the environment is a procedural right that cannot be separated from other rights. Regulations regarding community participation rights scattered in various environmental sector laws still contain antinomies that result in inconsistencies in the participation model and guarantee legal uncertainty. From here, efforts need to be made, such as ratifying the Declaration of the Right to Development into law and/or enacting a special law on community participation.

Keywords: Antinomy; Community; Participation; Rights; Environment
\end{abstract}

\section{Introduction}

Currently, in the midst of incessant infrastructure development in the natural resources sector to meet the needs of state administration, especially those carried out by the government, it is important for the community to participate and participate in carrying out development. The importance of community participation in carrying out development is carried out to adapt to existing development and development is carried out based on community needs. In a development, community participation is one aspect that needs to be considered. Community development is directed at improving people's living conditions. ${ }^{1}$ Community development as an effort to change the situation from less desirable to a better state. Therefore, community participation is one aspect that can determine the success of a development.

Participation means that people are actively and voluntarily involved, are involved on the basis of awareness or are involved on the basis that they feel they have the right to be involved. Community involvement in the development of economic structures, natural resources and infrastructure development in Indonesia in order to ensure the

\footnotetext{
${ }^{1}$ Muhammad Hasan \& Muhammad Azis, 2018, Pembangunan Ekonomi \& Pemberdayaan Masyarakat: Stategi Pembangunan Manusia Dalam Perspektif Ekonomi Lokal, Edisi Kedua. Makassar: Pustaka Tanam IImu. p. 14
} 
welfare of the community with policy directions that can follow the aspirations of the community. ${ }^{2}$ In the constitutional approach, the guarantee of the right to participate in the development process is regulated in the constitution article $28 \mathrm{C}$ paragraph 2 of the UUD of 1945; "Everyone has the right to advance himself in fighting for his rights collectively to build his community, nation and state", the implementation of this is regulated separately in the law in each sector.

The right to participate in the environmental development process is a separate right that is owned by every citizen, both individually and collectively, this can be carried out directly and indirectly and moves vertically and horizontally. It is called vertical participation because it occurs under certain conditions that the community is involved or takes part in a program of another party, in a relationship where the community is in the status of subordinates, followers or clients. While horizontal participation where the community has its own initiative where each person or community group participates horizontally with one another. This kind of participation is a sign of the beginning of the emergence of a society that is able to develop independently. ${ }^{3}$

As stipulated in the declaration of the right to development (accepted by the United Nations General Assembly through resolution No. 41/128, December 4, 1986) ${ }^{4}$, the right to development is an inalienable human right based on every human being and everyone has the right to participate and contribute to the enjoyment of economic, social, cultural and political development, if human rights and fundamental freedoms can be fully realized. All human beings have responsibilities in the development and preservation of the environment, individually and collectively, taking into account the need for full respect for human rights and fundamental freedoms such as their duties to the community, which can ensure freedom and complete fulfillment as human beings, and must also promote and protect political, social and economic measures.

The right to participate in development is born from the conception of democracy that the democratic system is considered a political reflection that guarantees the existence of government and the realization of development against the preferences and desires of its citizens. ${ }^{5}$ Community participation in development as a participatory right is in direct contact with the community, which is the first part that the government loses in the development process, both in the form of government actions to carry out development and the government's silence to turn a blind eye to community development needs. ${ }^{6}$

The recognition of the right of community participation in the implementation of development and the right to a good and healthy environment in the constitution

\footnotetext{
${ }^{2}$ Sri Hardianti, et,al., "Partisipasi Masyarakat Dalam Pembangunan Infranstruktur Desa (Program Alokasi Dana Desa Di Desa Buntongi Kecamatan Ampana Kota)," Jurnal Katalogis 5, no. 1 (2017): 120-26.

3 Tomy M Saragih, "Konsep Partisipasi Masyarakat Dalam Pembentukan Peraturan Daerah Rencana Detail Tata Ruang Dan Kawasan," Jurnal Sisa 17, no. 3 (2021): 14.

4 Deklarasi Hak Atas Pembangunan, 2014 , "Diterima Majelis Umum PBB Lewat Resolusi No. 41/128, 4 Desember 1986), Sumber Dari Referensi Elsam" .

${ }^{5}$ Heri Kusmanto, "Partisipasi Masyarakat Dalam Demokrasi Politik," Jurnal IImu Pemerintahan Dan Sosial Politik 1, no. 80-85 (2AD).

${ }^{6}$ H.S. Tisnanta, 2009, Partisipasi Publik Sebagai Hak Asasi Manusia Dalam Penyelengaraan Pemerintaha Daerah, Dalam Hak Asasi Manusia Hakikat, Konsep Dan Implikasinya Dalam Perspektif Hukum Dan Masyarakat. Bandung: Refika Aditama. p. 77
} 
becomes a reference for the legislature as a legislator to ensure the implementation of public participation itself, in the context of development which is directed to realize social justice in economic development, based on the management of natural resources under the provisions of Article 33 of the UUD 1945. The development is directed at providing human rights guarantees in the fulfillment of the right to good services for the poor in Indonesia by referring to Article 34 of the UUD 1945.

However, public law material, especially in the field of Indonesian administrative law, has not been able to function as a reinforcement in community empowerment and matters relating to community control over the government. ${ }^{7}$ Legislation in the field of environmental law and natural resources, for example, has proven to have failed to adequately place community participation as a subject in the implementation of development and so far participation has tended to be 'top-down/authoritarian'. There is no common link to arrive at the desired community participation in the 1945 Constitution, there are still differences in sound, and antinomy to the regulation of community participation in realizing development in an archipelagic state. In fact, community participation in the environment and natural resources sector should be positioned as an important element because this sector is a sector that determines the lives of many people. For this reason, this paper will focus on discussing how the concept and arrangement of community participation rights in development in the environmental secretariat are discussed by outlining the findings of the problem.

\section{Research Methods}

The method used in this study is a normative research method. Normative research method is research conducted by examining positive legislation/laws using library materials or secondary data. This can be seen in the main object examined in this Decision, namely the laws and regulations in the environmental sector (table 1). The approach method used in this research is a statutory approach and a conceptual approach. ${ }^{8}$ The main/primary legal materials used are statutory regulations. To assist the research, secondary legal materials are also used consisting of bibliographical literature such as books, research reports, journals, and the like that are supportive in nature.

\section{Results And Discussion}

\subsection{The Concept of Community Participation Rights in the Development of the Environmental Sector}

The right of community participation in development is a right that arises from the right to a healthy environment. Development in any sector is always intertwined with the environment, so that when entering the discourse on the right to participation, it

\footnotetext{
${ }^{7}$ kurniawan Hesti Puspitosari, khalikusabbir. 2016. Filosofi Pelayanan Publik. Makassar: Setara Press. p. 27

${ }^{8}$ Zainuddin Ali. 2016. Metode Penelitian Hukum. Jakarta: Sinar Grafika. p. 33
} 
cannot be separated from the right to a healthy environment, because it is part of the procedural rights of the right to a good and healthy environment. ${ }^{9}$

There is not a single living thing on this earth that does not need sufficient and healthy oxygen. All living things, both animals, plants and humans all need oxygen to breathe. The need for oxygen is met by the environment. That's just one small example of how the environment has a vital role in the existence of human life. To meet food needs, humans certainly really need clean water, clean water is not something that is down to earth, but comes from an environment that is sustainable, clean, and free from toxic waste.

The right to the environment is part of human rights, which have two forms that cannot be separated/reduced/limited, namely substantive rights and procedural rights. Substantive rights from the environment are rights that are derivatives or derivations of material rights. ${ }^{10}$ Material rights such as the right to life, the right to a decent standard of living and the right to health, the right to get intra and intergenerational justice. In short: substantive rights "support" of material rights. ${ }^{11}$ For example, the right to a good and healthy environment is a substantive right, this supports the fulfillment of the right to a decent standard of living. In addition, the right to a good and healthy environment supports the right to life because a good and healthy environment provides good air to breathe. The right to health (as a material right), in its realization, does not only take the form of access to health care, but also includes protection from environmental damage and pollution, such as radioactive contamination, water and food contamination. In the Indonesian context, substantive rights are guaranteed in Indonesian laws and regulations, namely Article 65 of the Law on Environmental Management and Protection, which states that "Everyone has the right to a good and healthy environment as part of human rights".

Next is the procedural rights to the environment. Procedural rights to the environment are a "supporting" element in realizing substantive environmental rights. The characteristics of these procedural rights are "active actions" carried out by humans, to participate so that substantive rights are realized, so that the forms of procedural rights to the environment such as, the right to information, the right to participate in decision making and the right to obtain access to justice. This procedural right to the right to the environment is regulated internationally by the 1998 Aarhus Convention, then adopted by Indonesia in various laws and regulations, one of which is Article 65 of the Law on Environmental Protection and Management, namely:

a. Everyone has the right to environmental education, access to information, access to participation, and access to justice in fulfilling the right to a good and healthy environment.

b. Everyone has the right to submit proposals and/or objections to business plans and/or activities that are estimated to have an impact on the environment.

\footnotetext{
9 Nopyandri, "Hak Atas Lingkungan Hidup Dan Kaitannya Dengan Peran Serta Dalam Pengelolaan Lingkungan Hidup Dalam Perspektif Otonomi Daerah," Jurnal Inovatif VII, no. III (2014): 36-38.

${ }^{10}$ Agung Wardana, "Hak Atas Lingkungan: Sebuah Pengantar Diskusi" Tulisan ini disajikan pada Karya Latihan Bantuan Hukum (Kalabahu) Lembaga Bantuan Hukum (LBH) Bali pada Jumat, 20 April 2012 di Denpasar (Denpasar, n.d.).

11 Kurniawan W. Sualang, "Hak Masyarakat Atas Lingkungan Hidup Yang Bik Dan Sehat," Lex Administratum 2, no. 2 (n.d.): 136.
} 
c. Everyone has the right to play a role in the protection and management of the environment in accordance with the laws and regulations.

d. Everyone has the right to make complaints due to allegations of environmental pollution and/or destruction.

Based on the elaboration of material rights, substantive rights and procedural rights to the environment, it can be understood that one right to another has a supporting relationship and relationship. Material rights are supported by substantive rights, while substantive rights are supported by procedural rights. On the scheme, it can be described simply as follows:

\section{Chart. 1}

The Relationship of Rights in the Environment

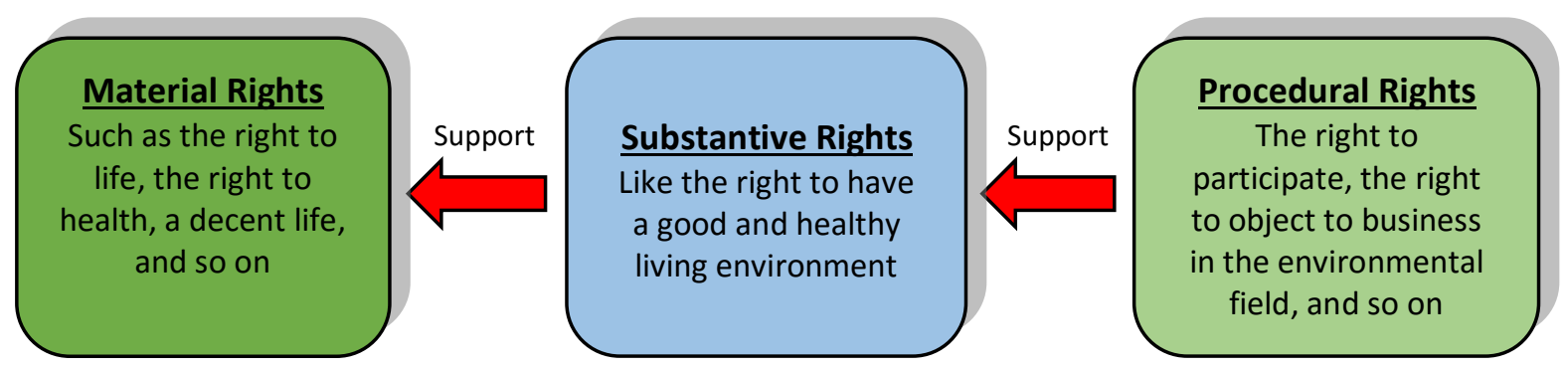

All of these rights, which then the state has the obligation to respect, protect, and fulfill. So significant a good and healthy environment for the sustainability of mankind. Fulfillment of this is the responsibility and obligation of the state, to respect, protect, and fulfill the rights to the human environment. In the form of an obligation to respect the right to the environment, namely:

a. The state must not allow/do damage to the environment on which human life depends.

b. Give respect to anyone, who struggles to protect and preserve the environment in any field (using their procedural rights)

The obligations to protect the right to the environment, namely:

a. The obligation to take steps in the field of legislation, in order to guarantee legal certainty for the right to the environment

b. Actively participate in environmental preservation, in order to maintain the existence of a sustainable environment

The obligations to fulfill are:

a. Provision of budget funds for environmental conservation.

b. Provide a response to any problems in the environmental field that interfere with the needs of human life.

c. Fulfill and implement all policies that are oriented towards every human being, in order to obtain the right to a good and healthy environment.

Environmental management is in dire need of law, without law, environmental management becomes undirected, and uncertain. In the past there was an assumption that the notion that human understanding and attention to nature as a place of life 
was only used as an object. Humans are not yet aware that between nature-the place where they live-and humans have the same position. The functions of "human" and "place of life" are equally important because they complement, depend and influence each other. On that basis, humans need to protect and maintain their place of life carefully, as humans maintain and protect themselves. ${ }^{12}$

The environment is no longer an object, but a subject that must be protected. So, the right instrument to provide protection is the law. If in the past the law was used conventionally-customary, such as "the customary prohibition to cut trees because it would damage the balance", now the legal paradigm has entered the era of postmodernism, where these rules are included in state law/statutory regulations. Koesnadi explained, there are 4 aspects that encourage the need for all environmental issues to be based on written legal rules, namely: ${ }^{13}$

a. Population and community development

b. Development of natural resources and the environment

c. Technological and cultural developments

d. Development of international scope

These four aspects are accompanied by the increasing complexity of environmental management which is faced with the need for high development. Therefore, humans as the main subjects who need a good and healthy environment, of course, have to be guaranteed their rights.

\subsection{Antinomy of Community Participation Rights in the Law on the Environmental Sector}

The face of Indonesian democracy which shifts public participation by being replaced with a representative system becomes a paralysis in democracy, which means that if citizens have exercised their right to vote in general elections, then the administration of the state will then be left to those who are elected in the government, such a conception of democracy. more often referred to as the concept of elite democracy. ${ }^{14}$ In the context of Indonesia, the concept of democracy has shifted to participatory democracy, given space by the legislature through several laws governing public participation, participatory democracy itself is a democracy that encourages community involvement in the formation and implementation of government policies. However, the election of representatives from the general election does not eliminate the participation of the community in participating in legal development and social development. if previously in the conception of elite democracy community involvement was limited, but in participatory democracy it provides opportunities for community participation so that development can translate to community needs, so

\footnotetext{
12 Hadin Muhjad. 2010. Hukum Lingkungan-Sebuah Pengantar Konteks Indonesia Jakarta: Raja Grafindo Persada. p. 3

${ }^{13}$ Kosenadi Harjasoemantri. 1996. Hukum Tata Lingkungan . Yogyakarta: Gajah Mada UP. p. 44

14 Saldi Isra. 2010. Pergeseran Fungsi Legislas Mengutanya Model Legislasi Parlementer Dalam Sistem Presidensil Di Indonesia. Jakata: Raja Grafindo Persada. p. 282
} 
that the conception and paradigm formed in participatory democracy is a democratic government but also creates a democratic society. ${ }^{15}$

Indonesia as a combination of a nomocracy and a democratic country, has its own view to position the people as the central subject in development. In Indonesia's view as a country with a nomocracy understanding, it is a consequence that all aspects of community life are regulated by law, but the regulation of aspects of legal life is not used as a way for the state to act in totalitarianism to regulate the personal matters of each individual member of society. ${ }^{16}$

The regulation of community participation using legal instruments is carried out with the basic rights owned by the community. As it is part of the legal arrangement, it is further explained by Paton, that legal rights are usually defined as rights that are recognized and protected by law. ${ }^{17}$ Jeremy Bentham, who stated that rights are children of law from real laws, real laws will arise, and vice versa, imaginary laws will only give rise to imaginary rights, so the regulation on the right to participate must be regulated by real law. The real law is reflected in the existence of legislators' legal products, where the law is categorized as the will of the legislator which is taken with a botom up mechanism. ${ }^{18}$

As a form of human rights that are continuously respected, valued, and fulfilled by the state, the translation of the right to participate in national development has been regulated in several organic laws which are attributable to the UUD 1945. Community participation in national development is described in the form of There are different forms of community participation in development which are depicted using direct participation and also indirect participation. So, in this case the author collects and compares seven laws that regulate community participation in terms of development.

\section{Table 1}

Community Participation in the Development of Natural Resources in Various Laws

\begin{tabular}{|c|l|l|l|}
\hline No & \multicolumn{1}{|c|}{ Regulation } & article & \multicolumn{1}{c|}{ Substance } \\
\hline 1 & $\begin{array}{l}\text { Act No. 32 of 2009 } \\
\text { concerning } \\
\text { Environmental } \\
\begin{array}{l}\text { Protection } \\
\text { Management }\end{array}\end{array}$ & $\begin{array}{l}\text { Article 70 } \\
\text { paragraph } \\
(1)\end{array}$ & $\begin{array}{l}\text { The community has the same and broadest rights and } \\
\text { opportunities to play an active role in environmental } \\
\text { protection and management. }\end{array}$ \\
\cline { 3 - 5 } & $\begin{array}{l}\text { Article 70 } \\
\text { paragraph } \\
(2)\end{array}$ & $\begin{array}{l}\text { Community roles can be in the form of: } \\
\text { a. social surveillance; } \\
\text { b. giving suggestions, opinions, proposals, objections, } \\
\text { complaints; and/or } \\
\text { submission of information and/or reports. }\end{array}$ \\
\cline { 3 - 5 } & $\begin{array}{l}\text { Article 70 } \\
\text { paragraph } \\
\text { (3) }\end{array}$ & $\begin{array}{l}\text { The role of the community is carried out to: } \\
\text { a. increase awareness in environmental protection and } \\
\text { management; } \\
\text { b. increasing independence, } \\
\text { empowerment, and partnerships; }\end{array}$ \\
\hline
\end{tabular}

\footnotetext{
15 Ibid.

${ }^{16}$ Satjipto Rahardjo. 2006. Ilmu Hukum . Bandung: Citra Aditya Bhakti. p. 206

17 Peter Mahmud Marzuki. 2016. Pengantar Ilmu Hukum. Jakarta: Kencana Press. p. 141

18 Jeremy Bentham. 2010. Teori Perundang-Undangan. Bandung: Nuansa Cendekia. p. 12
} 


\begin{tabular}{|c|c|c|c|}
\hline & & & $\begin{array}{l}\text { c. develop community capabilities and pioneers; } \\
\text { d. develop community responsiveness to carry out } \\
\text { social supervision; and e. develop and maintain local } \\
\text { culture and wisdom in the context of preserving } \\
\text { environmental functions. }\end{array}$ \\
\hline \multirow[t]{2}{*}{2} & \multirow[t]{2}{*}{$\begin{array}{l}\text { Act No. } 21 \text { of } 2014 \\
\text { concerning } \\
\text { Geothermal }\end{array}$} & $\begin{array}{l}\text { Article } 45 \\
\text { paragraph } \\
(1)\end{array}$ & $\begin{array}{l}\text { In implementing Geothermal, the community has a role } \\
\text { to play in: } \\
\text { a. maintain, protect, and preserve the area for } \\
\text { Geothermal exploitation activities; and } \\
\text { b. submit reports on the occurrence of hazards, } \\
\text { pollution, and/or environmental destruction in the } \\
\text { area of Geothermal exploitation activities. }\end{array}$ \\
\hline & & $\begin{array}{l}\text { Article } 45 \\
\text { paragraph } \\
(2)\end{array}$ & $\begin{array}{l}\text { In the implementation of Geothermal implementation, } \\
\text { the community has the right to: } \\
\text { a. obtain information related to Geothermal } \\
\text { exploitation through the Government or Regional } \\
\text { Government in accordance with their respective } \\
\text { authorities; } \\
\text { b. obtain benefits from Geothermal exploitation } \\
\text { activities through the company's obligation to fulfill } \\
\text { corporate social responsibility and/or development } \\
\text { of the surrounding community; } \\
\text { c. obtain appropriate compensation due to errors in } \\
\text { Geothermal exploitation activities in accordance } \\
\text { with the provisions of laws and regulations; and } \\
\text { d. file a lawsuit to the court against losses due to } \\
\text { Geothermal exploitation activities that violate the } \\
\text { provisions. }\end{array}$ \\
\hline \multirow[t]{2}{*}{3} & \multirow[t]{2}{*}{$\begin{array}{l}\text { Act No. } 39 \text { of } 2004 \\
\text { concerning } \\
\text { Plantations }\end{array}$} & $\begin{array}{l}\text { Article } \\
100 \\
\text { paragraph } \\
(1)\end{array}$ & $\begin{array}{l}\text { Plantation management is carried out by involving the } \\
\text { participation of the community. }\end{array}$ \\
\hline & & $\begin{array}{l}\text { Article } \\
100 \\
\text { paragraph } \\
(2)\end{array}$ & $\begin{array}{l}\text { Community participation as referred to in paragraph (1) } \\
\text { is carried out in the event that: } \\
\text { a. planning preparation; } \\
\text { b. area Development; } \\
\text { c. research and development; } \\
\text { d. financing; } \\
\text { e. empowerment; } \\
\text { f. supervision; } \\
\text { g. development of data and information systems; } \\
\text { h. institutional development; and/or i. } \\
\text { i. plantation arrangement. } \\
\text { j. business development guidelines. }\end{array}$ \\
\hline
\end{tabular}




\begin{tabular}{|c|c|c|c|}
\hline & & $\begin{array}{l}\text { Article } \\
100 \\
\text { paragraph } \\
\text { (3) }\end{array}$ & $\begin{array}{l}\text { The participation of the community as referred to in } \\
\text { paragraph ( } 2 \text { ) can be carried out in the form of providing } \\
\text { proposals, responses, filing objections, suggestions for } \\
\text { improvement, and/or assistance. }\end{array}$ \\
\hline \multirow[t]{5}{*}{4} & \multirow[t]{5}{*}{$\begin{array}{l}\text { Act No. } 32 \text { of } 2014 \\
\text { concerning marine } \\
\text { affairs }\end{array}$} & $\begin{array}{l}\text { Article } 70 \\
\text { paragraph } \\
(1)\end{array}$ & $\begin{array}{l}\text { The implementation of Marine Development is carried } \\
\text { out by the Government and Regional Governments by } \\
\text { involving the participation of the community. }\end{array}$ \\
\hline & & $\begin{array}{l}\text { Article } 70 \\
\text { paragraph } \\
(2)\end{array}$ & $\begin{array}{l}\text { The participation of the community as referred to in } \\
\text { paragraph (1) can be carried out individually, in groups, } \\
\text { professional organizations, business entities, or other } \\
\text { social organizations in accordance with the principles of } \\
\text { openness and partnership. }\end{array}$ \\
\hline & & $\begin{array}{l}\text { Article } 70 \\
\text { paragraph } \\
\text { (3) }\end{array}$ & $\begin{array}{l}\text { The participation of the community in Marine } \\
\text { Development as referred to in paragraph (1) is carried } \\
\text { out through participation in: } \\
\text { a. formulation of Marine Development policies; } \\
\text { b. Marine Management; } \\
\text { c. Marine development; and } \\
\text { d. provide input in evaluation and monitoring } \\
\text { activities. }\end{array}$ \\
\hline & & $\begin{array}{l}\text { Article } 70 \\
\text { paragraph } \\
\text { (4) }\end{array}$ & $\begin{array}{l}\text { Community participation other than as referred to in } \\
\text { paragraph (3) can be done through participation in: } \\
\text { a. preserving cultural values and maritime insights as } \\
\text { well as revitalizing customary law and local wisdom } \\
\text { in the marine sector; or } \\
\text { b. protection and socialization of underwater cultural } \\
\text { heritage through preservation, restoration, and } \\
\text { conservation efforts. }\end{array}$ \\
\hline & & $\begin{array}{l}\text { Article } 70 \\
\text { paragraph } \\
\text { (5) }\end{array}$ & $\begin{array}{l}\text { Further provisions regarding the forms and procedures } \\
\text { for community participation in Marine Development as } \\
\text { referred to in paragraph (1) shall be regulated in a } \\
\text { Government Regulation. }\end{array}$ \\
\hline 5 & $\begin{array}{l}\text { Act No. } 4 \text { of } 2009 \\
\text { concerning Mining }\end{array}$ & $\begin{array}{l}\text { Article } 1 \\
\text { point (i) }\end{array}$ & $\begin{array}{l}\text { development and improvement of community } \\
\text { participation in mining business by paying attention to } \\
\text { environmental sustainability }\end{array}$ \\
\hline
\end{tabular}




\begin{tabular}{|c|c|c|c|}
\hline \multirow[t]{3}{*}{6} & \multirow[t]{3}{*}{$\begin{array}{l}\text { Act No. } 18 \text { of } 2013 \\
\text { concerning } \\
\text { Prevention and } \\
\text { Eradication of } \\
\text { Forest Destruction }\end{array}$} & $\begin{array}{l}\text { Article } 58 \\
\text { paragraph } \\
(1)\end{array}$ & $\begin{array}{l}\text { Society has the right to: } \\
\text { a. good and healthy living environment, including the } \\
\text { quality of the environment produced by the forest; } \\
\text { b. forest utilization in accordance with the provisions } \\
\text { of laws and regulations; } \\
\text { c. community empowerment efforts; and } \\
\text { d. counseling on the importance of forest conservation } \\
\text { and the negative impact of forest destruction. }\end{array}$ \\
\hline & & $\begin{array}{l}\text { Article } 58 \\
\text { paragraph } \\
(2)\end{array}$ & $\begin{array}{l}\text { In addition to the rights as referred to in paragraph (1), } \\
\text { in the context of preventing and eradicating forest } \\
\text { destruction, the community has the right to: } \\
\text { a. seek and obtain information on the alleged } \\
\text { occurrence of forest destruction; } \\
\text { b. receive services in seeking, obtaining, and providing } \\
\text { information on allegations of forest destruction and } \\
\text { misuse of permits to law enforcement; } \\
\text { c. seek and obtain information on forest management } \\
\text { permits that have been issued by the local } \\
\text { government; } \\
\text { d. deliver suggestions and opinions responsibly to law } \\
\text { enforcement; and } \\
\text { e. obtain legal protection in: exercise their rights as } \\
\text { referred to in letters } a, b \text {, and c; }\end{array}$ \\
\hline & & Article 59 & $\begin{array}{l}\text { Society is obliged to: } \\
\text { a. maintain and maintain forest sustainability; and } \\
\text { b. manage forests in accordance with the provisions of } \\
\text { laws and regulations }\end{array}$ \\
\hline & & Article 60 & $\begin{array}{l}\text { The community is obliged to provide information, both } \\
\text { verbally and in writing, to the authorities if they know or } \\
\text { there are indications of forest destruction. }\end{array}$ \\
\hline & & Article 61 & $\begin{array}{l}\text { Communities take part in preventing and eradicating } \\
\text { forest destruction by: } \\
\text { a. establish and build a social network for the anti- } \\
\text { forest destruction movement; } \\
\text { b. involve and become partners of institutions for } \\
\text { eradicating forest destruction in forest destruction } \\
\text { prevention and eradication activities; } \\
\text { c. raise awareness about the importance of forest } \\
\text { conservation and the negative impact of forest } \\
\text { destruction; } \\
\text { d. provide information, both orally and in writing, to } \\
\text { the competent authorities regarding the prevention } \\
\text { and eradication of forest destruction; } \\
\text { e. participate in conducting supervision in law } \\
\text { enforcement to eradicate forest destruction; and/or } \\
\text { f. carry out other activities aimed at preventing and } \\
\text { eradicating forest destruction }\end{array}$ \\
\hline
\end{tabular}


In terms of community participation in national environmental development policies, it has an important role to ensure sustainable development. Community participation in national development is a benchmark for the benefits felt by the community in social life for a policy that will be used in national development or national development that has been held. The community can become the first level supporting element when the government as the Leading Sector of a policy is not able to provide the necessary resources due to the limited potential and capacity of the government, the existence of the community as an element outside the government can be the foundation and support for national development carried out systematically sustainable. ${ }^{19}$

To realize community participation as described above, it is necessary to develop a relationship between civil society, government and/or the private sector in order to achieve a goal based on the principles of trust, equality and independence. Theoretically, Oakley states that individuals as well as social groups and organizations, take part and influence the process of planning, implementing and controlling the passage of policies that affect their lives.

From this conceptual definition, the dimensions of community contribution are described in several types, namely the contribution of thoughts, contributions of funds, and contributions of energy. This is further constructed theoretically and also empirically from the observations made. At least there are stages of community participation according to Arstein. The eight levels mentioned above are explained as follows: ${ }^{20}$

a. Manipulation. In the name of participation, program participants are formally included in the program participant section, but without any involvement in program implementation. Its purpose is to be used as a mere formality and to be used for support. This level is not a genuine level of public participation, because it has been distorted and used as a means of publication by the authorities.

b. Therapy. The program makers regard helplessness as a mental illness. By pretending to include the community in a plan, they actually perceive the community as a group of people who need treatment. Although the community is involved in various activities, basically these activities aim to remove the wound and not find the cause of the wound.

c. Informing. Informing the public about their rights, responsibilities and choices is a very important first step in implementing community participation. However, often the provision of information from the authorities to the community is one-way, the community does not have the opportunity to provide feedback and does not have the power to negotiate. Moreover, when information is delivered at the end of planning, the community has little opportunity to influence the program. This one-way communication usually uses news media, namely brochures and posters.

\footnotetext{
19 Ibid.

${ }^{20}$ Sherry R. Arnstein, "A Ladder Of Citizen Participation," Journal of the American Planning Association (JAPA), n.d., 216.
} 
d. Consultation. Asking for public opinion is a logical step towards full participation. However, this consultation is still a quasi-participation, as there is no guarantee that their opinions will be taken into account. Frequently used methods at this level are polls, community meetings, and public hearings. If the power holder restricts the community's proposal, then the activity is only a false participation. Society is basically only considered as a statistical abstraction, because participation is only measured by the frequency of attendance at meetings, how many brochures are brought home and also by how many questionnaires are answered. Thus, the power holders have felt they have evidence that they have followed the series of community involvement.

e. Placation. At this level the community already has some influence although in some cases this influence has no guarantee of being noticed. The community is indeed allowed to provide input or propose plans, but it is the power holder who has the authority to determine. One strategy is to select poor people who are eligible to be included in an institution. If they are not in charge and if the power holders have a majority of the seats, then they will be easily defeated and outsmarted.

f. Partnerships. At this level power is channeled through negotiations between the power holder and the community. They agreed to share responsibility for planning and decision making. The rules are determined through a take and give mechanism, so it is not expected to change unilaterally. Partnerships can be effective if there is an organized power in the community, the leaders are responsible, the community is able to pay adequate fees for its leaders and there is a source of funds to hire technicians, lawyers and community organizers. Thus, the community really has a high bargaining position, so that it will be able to influence a plan.

g. Delegated Power. Negotiations between the community and government officials can result in the dominance of authority in the community over certain plans or programs. At this level the community occupies the majority of seats, so it has the power to determine a decision. In addition, the community also plays an important role in ensuring the accountability of the program. To overcome differences, power holders do not need to respond but by holding a bargaining process.

h. Citizen Control. At this level, the community wants a guarantee that the authority to regulate programs or institutions is given to them, is fully responsible for policies and managerial aspects and can conduct

However, from the legislation that regulates community participation dominantly it is only regulated in 1 article, the arrangement has various forms and types of community participation, this will be described by the author in several examples of legislation as follows:

The difference in the guarantee of community participation in the law as referred to in Article 100 paragraph (2) of Law Number 39 of 2014 concerning Plantations guarantees community participation with "Community participation as referred to in paragraph (1) is carried out in terms of: planning preparation; area Development; research and development; financing; empowerment; supervision; development of 
data and information systems; institutional development; and/or plantation arrangement business development guidelines.

The law above provides opportunities for community participation from the beginning of planning to guidelines for plantation business development, even providing a space for community empowerment. However, different participation can be found in Article 70 paragraph (2) of Law Number 32 of 2009 concerning Environmental Protection and Management.

The role of the community can be in the form of: social surveillance; giving suggestions, opinions, proposals, objections, complaints; and/or submission of information and/or reports. The regulation in the article is only limited to 3 aspects, namely social supervision, giving advice and delivering information. This is narrower when compared to the provisions in the Plantation Law, even in the environmental sector which is much more important for the survival of the community, community participation is limited and ascribed to environmental management. This closes the tap of community participation on the rights they have, which is regulated in article 65 that "Everyone has the right to environmental education, access to information, access to participation, and access to justice in fulfilling the right to a good and healthy environment".

In a different law, in the article Apart from the rights as referred to in article 58 paragraph (1) of Law Number 18 of 2014 concerning the Prevention and Eradication of Forest Destruction, the community has the right to:

a. seek and obtain information on allegations of forest destruction having occurred; receive services in seeking, obtaining, and providing information on allegations of forest destruction and misuse of permits to law enforcement;

b. seek and obtain information on forest management permits that have been issued by the local government;

c. deliver suggestions and opinions responsibly to law enforcement; and

d. obtain legal protection in: exercising their rights as referred to in letters $a, b$, and $\mathrm{c}$; and

e. obtain legal protection in: 1 ) exercise their rights as referred to in letters $a, b$, and $\mathrm{c}$; and 2) the process of investigation, investigation, and trial as a reporting witness, witness, or expert witness in accordance with the provisions of the laws and regulations

The occurrence of legal antinomies that exist in the national legal system, especially in the implementation of national development makes community participation carried out differently the community's understanding of such laws tends to prevent people from exercising their rights to participate in development or abandoning their rights.

This is what distorts the meaning of society towards the law, the law is actually believed to be a tool or instrument to bring justice, benefit and legal certainty, but paralysis of the meaning of law occurs. Fairly, proportionally and with certainty to ratify this claim cannot be separated from the law contained in the state law, the people request that the actions taken are in accordance with a higher norm than the legal norms contained in the law. ${ }^{21}$

${ }^{21}$ Theo Huijbers. 1982. Filsafat Hukum Dalam Lintas Sejarah. Yogyakarta: Pustaka Filsafat. p. 273 
Imperfections in the meaning of law in society occur when laws made in the form of laws do not have legal certainty, with different forms and sounds of the law against the same object and the same subject. Disharmonization of laws governing public participation can lead to certain interpretations and certain conditions for the same object, in the science of legislation there is a principle of conformity between the types of content contained in the law, which principle requires that the formation of legislation The correct legislation must pay attention to the right content material with the type of legislation, so that there are no legal conflicts and disharmony in the sound of the article. ${ }^{22}$ This situation can damage the function of legislation in the process of law formation which leads to the birth of legal uncertainty and differences in treatment between the same legal subject and the same object.

Legal certainty is an aspired goal in development, legal certainty is an aspect of legal axiology of legal positivism. Legal ontology, in legal positivism, is defined as a set of rules made by the authorities, and systematized between one sub-system and another. Shidarta explained that the ontology in legal positivism is positive norms in the legal system. This meaning reflects the amalgamation of idealism and materialism. Such an explanation can refer to the will theory of law from John Austin and the pure norm theory of law from Hans Kelsen. ${ }^{23}$ According to Austin, a positive legal rule is to equated with the expression of an act of wishing, sedangkan A legal system is to be equated with all the positive legal rule emanating from the sovereign will. ${ }^{24}$

What is stated above is an ideal aspect in the formation of law, but with the diversity and incompatibility of forms of community participation in various organic laws, the legal objectives are not achieved, the law is only made as a product that will support the interests of those who have different interests. is actually in it, so that such a regulatory mechanism seems to emphasize the participation rights of the community in carrying out development.

The existence of differences in sound and recognition of community participation in various laws not only leads to unclear benchmarks for community participation in the development process which is essentially to realize social welfare, we can find these differences in various laws that have been described in the table. This legal certainty is in line with the opinion of E. Fernando M. Manulang, who stated that the notion of legal certainty is a value that in principle provides legal protection for every citizen from arbitrary power, so that the law gives the state responsibility to run it. the issue of legal certainty with the state. Soedikno Mertokusumo mentions legal certainty as judicial protection against arbitrary actions, which means that a person will be able to obtain something that is expected under certain circumstances. These circumstances will have a negative impact.

The negative impact of uncertain and incompatible laws is that they can injure the principle of equality before the law in the application of the law. This is because due to differences in regulations, the legal treatment of the community will be different. In the conception of the rule of law as explaining the main element in the rule of law is

\footnotetext{
${ }^{22}$ Maria Farida. 2007. Ilmu Perundang-Undangan Jenis, Fungsi Dan Materi Muatan. Jakarta: Kanisius. p. 243

${ }^{23} \mathrm{Ibid}$.

${ }^{24}$ Shidarta. 2013. Hukum Penalaran Dan Penalaran Hukum. Yogyakarta: Genta Publishing. p. 198
} 
that all life of the nation and state is regulated by using law, in the midst of the functioning of the law by using positive law as a form of law which is used to ensure the fulfillment of legal certainty as the purpose of the law itself.

In the conception of the rule of law with the main goal of upholding legal certainty, it is carried out using several main principles, one of which is the principle of equality before the law, which is a principle that positions legal subjects with the same position, equality before the law, either individually or in groups who have rights. and obligations protected by law as legal subjects.

In the conception of the rule of law, legal certainty has its own relationship with the principle of Equality before the law, in the conception of the need for regulations based on laws or the idea of legal certainty can only be realized in the conception of legal positivism alone, as well as the combination of the relationship between equality before the law in treating legal subject. Such equality of position can only be upright and universally applicable when there are written regulations governing it. ${ }^{25}$

Such a practice is certain to have violated the principle of non-discrimination, by enforcing the law in a discriminatory manner as well as enslaving the law from its main function, namely creating justice. The enactment of discriminatory laws carried out by law opens up opportunities that people in certain sectors and certain areas feel subordinated to community participation which cannot be implemented completely, and feel disadvantaged for a development carried out. This shows that there is doubt in the government to have a national perspective consistently in fulfilling the rights of the people.

Different and discriminatory treatment, which violates the principle of equality before the law, is carried out by the state on forms of community participation which are separated based on smaller sectors of natural resource management in certain fields, such as for example in the case of community geothermal management. in geothermal mining islands, such as Sumatra (81 locations), Java (71 locations), Nusa Tenggara (27 locations), Maluku (15 locations), North Sulawesi (7 locations), Bangka Belitung (3 locations), Kalimantan (2 locations) and also Papua (2 locations) ${ }^{26}$, which is a map of the implementation of oil mining in Indonesia to get participation or participation in the form of: 1) maintain, protect, and preserve the area for Geothermal exploitation activities; and 2) submit reports on the occurrence of hazards, pollution, and/or environmental destruction in the area of Geothermal exploitation activities.

In the implementation of business and development based on natural resource management in the geothermal sector, it only provides 2 forms of public participation, this derogates the theory of the level of community participation and only regulates it narrowly, and only applies to the community environment with a map of the implementation of the geothermal mining business.

In the plantation sector, different treatment for the practice of community participation as regulated in the provisions of Article 100 paragraph (1) Community participation as referred to in paragraph (1) is carried out in terms of: (a) planning

25 Budiono Kusumahamidjojo. 2011. Filsafat Hukum: Probematikan Ketertiban Yang Adil (Bandung: Mandar Maju. p. 218

${ }^{26}$ Rina Wahyuningsih, "Potensi Dan Wilayah Kerja Pertambangan Panas Bumi Di Indonesia," Makalah PB Potensi Dan WKP Panas Bumi, n.d., psdg.bgl.esdm.go.id. 
preparation; (b) area development; (c) research and development; (d) financing; (e) Empowerment; (f) supervision; (g) development of data and information systems; (h) institutional development; and/or (i) preparation of Plantation Business development guidelines. This is only limited to the participation of community members in the implementation of plantations.

From the comparison of the two laws above, it shows that there are unequal practices in the implementation of community participation rights because they are limited by the sector of development business carried out, so that in terms of geothermal management as described in the first law, the community feels disadvantaged because the community is not included in the planning and execution process of development. In the end, the antinomy of regulating public participation in organic law will make the law lose its authority as a regulatory norm. So that the enthusiasm of the community in carrying out their participation is lost. ${ }^{27}$

In the midst of the legal antinomy that occurs against the recognition of the right of community participation in development, a solution is urgently needed to dismantle the national legal system by forming a new legal product. General United Nations through resolution No. 41/128, December 4, 1986) as a product of national law through a law, this can be done as emphasized in Article 10 of Law No. 12 of 2011 concerning the Establishment of Legislation, stating that the material from statutory regulations.

The purpose of the ratification is as an independent legal umbrella for the right to development which opens up opportunities for the people to participate in environmental development.

The second step is to form a Special Law (Lex Specialist) which regulates community participation and the types and levels of community participation owned by the community. The arrangement is a follow-up to the ratification of the Declaration on the Right to Development. The establishment of a special law that regulates the right to development becomes a reference for other laws in regulating participation rights in organic laws. The establishment of this special law is to accommodate the human rights of every citizen to participate. The substances that can be input are:

a. The public has the right to participate at every level of the procedure

b. Considerations originating from the community have the power to determine in determining the development process

c. Obligations for stakeholders and the government, to absorb aspirations in every development.

As a special form of law that regulates community participation in development, the formation of legal product laws by using lex specialist law, which is one of the principles of preference is a legal principle that is able to show that the law takes precedence (to be enforced) if the rule of law occurs antinomy. Pernandi Purbacaraka and Soejono Soekanto stated that the purpose of this principle is that it is mandatory for a law to enact a special event that mentions the event, even though in such a legal event a law can be enacted which mentions it more broadly. The two efforts above are believed to be a way out to harmonize legal norms governing community participation in development.

27 Ibid. 


\section{Conclusion}

The regulation of community participation that is spread out in organic law still has shortcomings, the deficiency is in the form of non-uniformity in the regulation of community participation in the law, such an arrangement creates legal uncertainty. The existence of different arrangements gives rise to different treatment, from the legal uncertainty contained in the law causing in-equality legal treatment of public participation, so that there is a form of discrimination against participation rights that are not fully recognized in various laws. laws ranging from planning to controlling carried out by the community, so that the community feels subordinated to the law. In fact, development, especially in the environmental field, is a derivative of article 33 of the 1945 Constitution concerning natural resources, because it has the same basis, then laws at the level of law must also have similarities in involving community participation. The solution offered is firstly done by ratifying the Declaration on the Right to Development (accepted by the UN General Assembly through resolution No. 41/128, December 4, 1986) and establishing a special law on public participation.

\section{References}

\section{Journal}

[1] Agung Wardana. "Hak Atas Lingkungan: Sebuah Pengantar Diskusi." Agung Wardana, "Hak Atas Lingkungan: Sebuah Pengantar Diskusi" Tulisan ini disajikan pada Karya Latihan Bantuan Hukum (Kalabahu) Lembaga Bantuan Hukum (LBH) Bali pada Jumat, 20 April 2012 di Denpasar, n.d.

[2] Heri Kusmanto. "Partisipasi Masyarakat Dalam Demokrasi Politik." Jurnal Ilmu Pemerintahan Dan Sosial Politik 1, no. 80-85 (2AD).

[3] Kurniawan W. Sualang. "Hak Masyarakat Atas Lingkungan Hidup Yang Bik Dan Sehat." Lex Administratum 2, no. 2 (n.d.): 136.

[4] Nopyandri. "Hak Atas Lingkungan Hidup Dan Kaitannya Dengan Peran Serta Dalam Pengelolaan Lingkungan Hidup Dalam Perspektif Otonomi Daerah." Jurnal Inovatif VII, no. III (2014): 36-38.

[5] Sherry R. Arnstein. "A Ladder Of Citizen Participation." Journal of the American Planning Association (JAPA), n.d., 216.

[6] Sri Hardianti, et.al. "Partisipasi Masyarakat Dalam Pembangunan Infranstruktur Desa (Program Alokasi Dana Desa Di Desa Buntongi Kecamatan Ampana Kota)." Jurnal Katalogis 5, no. 1 (2017): 120-26.

[7] Tomy M Saragih. "Konsep Partisipasi Masyarakat Dalam Pembentukan Peraturan Daerah Rencana Detail Tata Ruang Dan Kawasan." Jurnal Sisa 17, no. 3 (2021): 14.

[8] Wahyuningsih, Rina. "Potensi Dan Wilayah Kerja Pertambangan Panas Bumi Di Indonesia." Makalah PB Potensi Dan WKP Panas Bumi, n.d. psdg.bgl.esdm.go.id.

\section{Books}

[1] Ali, Zainuddin. 2016. Metode Penelitian Hukum. Jakarta: Sinar Grafika

[2] Azis, Muhammad Hasan \& Muhammad. 2018. Pembangunan Ekonomi \& Pemberdayaan Masyarakat: Stategi Pembangunan Manusia Dalam Perspektif 
Ekonomi Lokal. Edisi Kedua. Makassar: Pustaka Tanam Ilmu.

[3] Budiono Kusumahamidjojo. 2011. Filsafat Hukum: Probematikan Ketertiban Yang Adil. Bandung: Mandar Maju.

[4] Deklarasi Hak Atas Pembangunan. diterima Majelis Umum PBB lewat resolusi No. 41/128, 4 Desember 1986), Sumber dari Referensi Elsam .

[5] Farida, Maria. 2007. Ilmu Perundang-Undangan Jenis, Fungsi Dan Materi Muatan. Jakarta: Kanisius.

[6] H.S. Tisnanta. 2009. Partisipasi Publik Sebagai Hak Asasi Manusia Dalam Penyelengaraan Pemerintaha Daerah, Dalam Hak Asasi Manusia Hakikat, Konsep Dan Implikasinya Dalam Perspektif Hukum Dan Masyarakat. Bandung: Refika Aditama.

[7] Hadin Muhjad. 2010. Hukum Lingkungan-Sebuah Pengantar Konteks Indonesia. Jakarta: Raja Grafindo Persada.

[8] Hesti Puspitosari, khalikusabbir, kurniawan. 2016. Filosofi Pelayanan Publik. Makassar: Setara Press.

[9] Jeremy Bentham. 2010. Teori Perundang-Undangan. Bandung: Nuansa Cendekia.

[10] Kosenadi Harjasoemantri. 1996. Hukum Tata Lingkungan. Yogyakarta: Gajah Mada UP.

[11] Marzuki, Peter Mahmud. 2016. Pengantar Ilmu Hukum. Jakarta: Kencana Press.

[12] Rahardjo, Satjipto. 2006. Ilmu Hukum. Bandung: Citra Aditya Bhakti.

[13] Saldi Isra. 2010. Pergeseran Fungsi Legislas Mengutanya Model Legislasi Parlementer Dalam Sistem Presidensil Di Indonesia. Jakata: Raja Grafindo Persada.

[14] Shidarta. 2013. Hukum Penalaran Dan Penalaran Hukum. Yogyakarta: Genta Publishing.

[15] Theo Huijbers. 1982. Filsafat Hukum Dalam Lintas Sejarah. Yogyakarta: Pustaka Filsafat. 